\title{
EEF1G Gene
}

National Cancer Institute

\section{Source}

National Cancer Institute. EEF1G Gene. NCI Thesaurus. Code C38965.

This gene is involved in the synthesis of proteins. 